\title{
RELATIONSHIP BETWEEN NUMERICAL ABILITY, ATTENTION OF PARENTS AND INTEREST IN LEARNING WITH RESULTS OF STUDENT LEARNING MATHEMATICS OF CLASS VII
}

\author{
Latifah Fitriasaria, Suparyan $^{\mathrm{b}}$ \\ Program Studi Pendidikan Matematika Universitas Ahmad Dahlan \\ Jalan Ring Road Selatan, Tamanan, Banguntapan, Bantul Yogyakarta

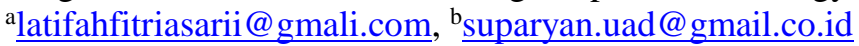

\begin{abstract}
Based on information from SMP Negeri 15 Yogyakarta, low numerical abilities, lack of parental attention and low student learning interest. This study aims to determine whether there is a positive and significant relationship between numerical ability, parental attention and interest in learning with mathematics learning outcomes of class VII students of SMP Negeri 15 Yogyakarta even semester 2015/2016 academic year. The population in this study were all regular VII grade students of SMP Negeri 15 Yogyakarta even semester 2015/2016 academic year as many as 5 classes. Class VII C was taken as the research sample class with a random sampling technique for the class. Data collection techniques in the form of questionnaires and test techniques. The research instrument was in the form of a questionnaire for variables of parental attention and variables of interest in learning while the research instruments were in the form of tests for numerical ability variables and mathematics learning outcomes variables. Test of research instruments used validity tests, different power tests, and reliability tests. Analysis prerequisite test includes a normality test, independent test and linearity test. Data analysis for hypothesis testing using product-moment correlation analysis and multiple linear regression analysis. The results showed a positive and significant relationship between (1) the numerical skills with mathematics learning outcomes, with $r=0.4176780979$; (2) The parent's attention with mathematics learning outcomes, with $r=0.4826111448$; (3) interest in learning with mathematics learning outcomes, with $\mathrm{r}=0.2873655253$; (4) The numerical skills and parents attention with math learning outcomes, with $R=0.5921931342$; (5) The numerical skills and interest in learning with mathematics learning outcomes, with $R=0.4314264425$; (6) The parents attention and interest in learning with mathematics learning outcomes with $R=0.5623422638$; (7) The numerical skills, parents attention and interest in learning with mathematics learning outcomes, with $R=0.609887925$ and the linear regression equation $\mathrm{Y}=-14.81581646+0.2860704335 X_{1}+0.7994211603 X_{2}+0.2860704335 X_{3}$. Large donations are relatively $X_{1}=30.35, X_{2}=56.92 \%$ and $X_{3}=12.73 \%$ and the effective contribution $X_{1}=11.29 \%, X_{2}=$ $21.17 \%$ and $X_{3}=4.73 \%$.
\end{abstract}

Keywords: Numerical Skills, Parents Attention, Interest in Learning, Learning Outcomes

\section{INTRODUCTION}

Understanding "education" according to Muhibbin Shah (2011: 10), states that Education in English, education (education) comes from the word educate (educating) means to give an increase (to elicit, to give rise to), and develop (to evolve, to develop). In a narrow sense, education or education means an act or process of action to gain knowledge (McLeod, 1989).

Mathematics is a basic science that must be mastered in developing science and technology. Mathematics also plays an important role in the development of logical, analytical, systematic and creative thinking skills. But mathematics is one of the lessons that are not liked by some students, because mathematics is often felt scary, boring, and felt difficult to learn. Learning mathematics is different from other lessons that can be learned only by memorizing. Therefore, numerical skills are needed in solving mathematical problems. The assumption that mathematics, in general, is always associated with something difficult and abstract. So that the results of mathematics become one of the fields of study that are generally considered to be the most difficult and boring for students. Besides that, it was strengthened by the teaching teacher of mathematics subjects at SMP Negeri 15 Yogyakarta who said that students' ability to count was still lacking. This reason is the reason students have difficulty learning mathematics and are reluctant to learn it. 
The first education for personality development and children's education is family. This is because a child knows education from the family. All attitudes and behavior of parents greatly influence children's development. Parents must be able to monitor the learning process of their children properly. Motivation from parents must also exist because most of the time students are more at home.

Based on information from seventh-grade students of SMP Negeri 15 Yogyakarta on October 20, 2015, many parents considered that children's education problems were entirely school responsibility. If the child is at school age, most parents pay less attention to the development of their child's education. Parents think that if they have fulfilled their school needs and facilities, then they have sufficiently fulfilled their responsibilities as parents to their children. The attention of parents is very necessary for an effort to improve the learning outcomes of mathematics, both in the form of support and encouragement in learning and the provision of facilities that can support students in learning.

Based on the results of observations and information from class VII students of SMP Negeri 15 Yogyakarta on October 20, 2015, in the process of learning mathematics, some students lacked interest in mathematics, because according to students mathematics lessons were a difficult lesson. If the lesson material is not in accordance with students' interest in learning, then students are not enthusiastic to pay attention because there is no attraction for him. Inevitably, the low interest in student learning during the teaching and learning activities in the classroom will have a direct impact on the understanding and mastery of mathematics subject matter. Understanding and mastery of mathematics subjects that are not good which causes difficulties in learning mathematics. Though in learning mathematics interest is very necessary.

According to Dimyati and Mudjiono (2013: 3), that learning outcomes are the result of an interaction between learning and teaching. From the teacher's side, teaching action ends with a process of evaluating learning outcomes. In terms of students, learning outcomes are the ending and the peak of the learning process. The low mathematics learning outcomes of class VII students of SMP Negeri 15 Yogyakarta can be seen from the average mathematics scores at the end of semester examinations which are still low. The math scores of the final semester VII grade of SMP Negeri 15 Yogyakarta are more than $50 \%$ below the KKM standard. This proves that there are still many students who have difficulty learning mathematics.

Based on the background and limitations of the problem, then the problem can be formulated to be examined, namely is there a positive and significant relationship between numerical ability, parental attention, and interest in learning with mathematics learning outcomes of seventh-grade students of SMP Negeri 15 Yogyakarta even semester 2015/2016?

The purpose of this research is to find out whether there is a positive and significant relationship between numerical ability, parental attention and interest in learning with the mathematics learning outcomes of class VII students of SMP Negeri 15 Yogyakarta even semester 2015/2016?

\section{METHODS}

This research is classified as quantitative research. The place of research was conducted in SMP Negeri 15 Yogyakarta. While the time of the study was carried out in the even semester of the 2015/2016 academic year. The population in this study were all VII grade students in even semester 15 of Yogyakarta which consisted of 5 classes which were all homogeneous because the classes were arranged randomly without superior classes. In this study, samples were taken randomly using random sampling techniques for the class. It was said to be random because the sample taking was done randomly from the existing class because the ability of each class in the population was the same and what was taken as the sample class was class VII C with as many as 34 students.

The research variables are two variables, namely the independent variable (independent) and the dependent variable (dependent). Independent variable (Independent) consists of numerical abilities $\left(\mathrm{X}_{1}\right)$, parental attention $\left(\mathrm{X}_{2}\right)$ and interest in learning $\left(\mathrm{X}_{3}\right)$, while the dependent variable is the learning outcomes of mathematics (Y). Data collection techniques used questionnaires and test methods. In this study, the questionnaire method was used to obtain data pertaining to parent and students learning 
interests. While the test method is used to obtain data on numerical abilities and mathematics learning outcomes of class VII students in SMP Negeri 15 Yogyakarta.

The questionnaire instrument test used the content validity test by the reviewer and the instrument reliability test with alpha formula, while the question instrument test used instrument validity test with product-moment correlation technique, different power test and instrument reliability test with the KR-20 formula (Suharsimi Arikunto. 2009: 100) After the data is collected, an analysis prerequisite test that must be fulfilled includes normality test, linearity test, and independence test. Data analysis using product-moment correlation analysis and multiple linear regression analysis.

\section{RESULTS AND DISCUSSION}

In this section, a further discussion of the results of the study was analyzed correlation. This study found that the seventh hypothesis test results were a positive and significant relationship between numerical abilities, parental attention and students' interest in learning with mathematics learning outcomes. In other words, the better the numerical abilities of students, the better the learning outcomes will be. Likewise, with the attention of parents, the higher parents give attention to their children as much as possible, the higher the learning outcomes. In addition, interest in learning also affects learning outcomes, because if the interest in learning is high then the learning outcomes will also be higher. In this study also uses analysis preliminary tests which include:

1. Test for normality

This normality test is used to test the distribution of data obtained by each variable whether it is normally distributed or not. The summary results of the normality test of the four variables are:

Table 1. Summary of normality Test

\begin{tabular}{|c|l|r|r|c|c|}
\hline No & \multicolumn{1}{|c|}{ Variable } & $\boldsymbol{\chi}_{\text {count }}^{\mathbf{2}}$ & $\boldsymbol{\chi}_{\text {table }}^{\mathbf{2}}$ & Df & Info \\
\hline 1 & Numerical Ability $\left(X_{1}\right)$ & 5,046 & 9,488 & 4 & Normal \\
\hline 2 & Parents attention $\left(X_{2}\right)$ & 1,088 & 7,815 & 3 & Normal \\
\hline 3 & Interest to learn $\left(X_{3}\right)$ & 2,207 & 9,488 & 4 & Normal \\
\hline 4 & $\begin{array}{l}\text { Mathematics Learning } \\
\text { Results }(Y)\end{array}$ & 3,687 & 5,992 & 2 & Normal \\
\hline
\end{tabular}

2. Test of independence

Independence test is used to find out whether or not there is a relationship between independent variables. The summary of the independence test results from the three independent variables are:

Table 2. Summary of independence test

\begin{tabular}{|c|c|c|c|c|c|}
\hline No & Variable & $\boldsymbol{\chi}_{\text {count }}$ & ${\boldsymbol{\chi ^ { 2 }}}_{\text {table }}$ & Df & Info. \\
\hline 1 & $X_{1}$ against $X_{2}$ & 32,451 & 43,775 & 30 & Independent \\
\hline 2 & $X_{1}$ against $X_{3}$ & 22,433 & 43,775 & 30 & Independent \\
\hline 3 & $X_{2}$ against $X_{3}$ & 21,308 & 37,652 & 25 & Independent \\
\hline
\end{tabular}

3. Test linearity

Linearity test is used to find out between the independent variable and the dependent variable whether it has a linear relationship or not. The summary results of the linearity test of the four variables are:

Table 2. Summary of the linearity test

\begin{tabular}{|l|l|l|l|l|}
\hline No & Variable & $F_{\text {count }}$ & $F_{\text {table }}$ & Info. \\
\hline 1 & $X_{1}$ against $Y$ & 0,124 & 2,355 & Linear \\
\hline 2 & $X_{2}$ against $Y$ & 0,233 & 2,413 & Linear \\
\hline 3 & $X_{3}$ against $Y$ & 0,313 & 2,5436 & Linear \\
\hline
\end{tabular}


4. Hypothesis testing

From the multiple correlation analysis, the multiple correlation coefficient $(\mathrm{R})$ is 0.610 . In this study also obtained the coefficient of determination $\left(\mathrm{R}^{2}\right)$ of 0.372 meaning the variance of mathematics learning outcomes $(\mathrm{Y})$ which can be explained by numerical abilities $\left(\mathrm{X}_{1}\right)$, parental attention $\left(\mathrm{X}_{2}\right)$, and interest in learning $\left(\mathrm{X}_{3}\right)$ through linear lines $\hat{Y}=-14,816+0,367 X_{1}+$ $0,799 X_{2}+0,286 X_{3}$. This means that the increase of one unit $\left(X_{1}\right)$ results in a 0.367 increase in $\mathrm{Y}$, an increase of one unit $\left(\mathrm{X}_{2}\right)$ resulting in a 0.799 increase in $\mathrm{Y}$, and the use of one unit $\left(\mathrm{X}_{3}\right)$ results in 0.286 increase in $\mathrm{Y} . \mathrm{X}_{3}$ is $12.726 \%$ and the effective contribution of $\mathrm{X}_{1}$ is $11.289 \%, \mathrm{X}_{2}$ is $21.174 \%$ and $\mathrm{X}_{3}$ is $4.733 \%$. This shows that parents' attention provides a more significant relationship to mathematics learning outcomes compared to numerical abilities and interest in learning.

\section{CONCLUSION}

Based on the results of the research and discussion as described above, it can be concluded that there is a positive and significant relationship between numerical ability, parental attention and interest in learning with mathematics learning outcomes of class VII students of SMP Negeri 15 Yogyakarta even semester 2015 / 2016 This is indicated by the - F test which is $F_{\text {count }}>F_{\text {table }}$ or 5,923 $>2,92$ with a multiple correlation coefficient $(\mathrm{R})$ of 0.610 and a coefficient of determination $\left(\mathrm{R}^{2}\right)$ of 0.372 . Linear regression equation $\hat{Y}=-14,816+0,367 X_{1}+0,799 X_{2}+0,286 X_{3}$. The relative contribution of $X_{1}$ is $30.351 \%, X_{2}$ is $56.924 \%$ and $X_{3}$ is $12.726 \%$ and the effective contribution of $X_{1}$ is $11.289 \%, X_{2}$ is $21.174 \%$ and $X_{3}$ is $4.733 \%$.

\section{REFERENCES}

Arikunto,Suharsimi.2012.Dasar-Dasar Evaluasi Pendidikan.Jakarta:Bumi Aksara.

2009.Dasar-Dasar Evaluasi Pendidikan.Jakarta:Bumi Aksara.

Baharuddin dan Wahyuni,Esa Nur.2012.Teori Belajar dan Pembelajaran. Yogyakarta:Ar-Ruzz Media.

Chandra, Aristo dan Tim.2014.Fresh Update Top No.1 Psikotes.Jakarta: Wahyu Media.

Dimyati dan Mudjiono.2013.Belajar dan Pembelajaran.Jakarta:PT Rineka Cipta.

Fudyartanta.2010.Tes Bakat dan Perskalaan Kecerdasan.Yogyakarta:Pustaka Pelajar.

Hamalik,Oemar.2013.Kurikulum dan Pembelajaran.Jakarta:PT Bumi Aksara.

Idris,Mardjoko.2015.Islam Interdisipliner.Yogyakarta : Universitas Ahmad Dahlan.

Khasanah,Uswatun.2014.Analisis Regresi.Yogyakarta:Universitas Ahmad Dahlan.

Mustaqim,H.2012.Psikologi Pendidikan.Yogyakarta:Pustaka Pelajar Offset.

Naga,Dali S.1980.Berhitung: Sejarah dan Pengembangannya.Jakarta: PT Gramedia.

Purwanto.2011.Evaluasi Hasil Belajar.Yogyakarta:Pustaka Pelajar.

Suherman,Erman,dkk.2003.Strategi Pembelajaran Matematika Kontemporer. Bandung:JPMIPA

Universitas Pendidikan Indonesia.

Sugiyono.2010.Metode Penelitian Pendidikan (Pendekatan Kuantitatif, Kualitatif dan $R \& D$. Bandung:AlfaBeta.

Slameto.2010.Belajar dan Faktor-faktor yang Mempengaruhi.Jakarta:Rineka Cipta.

Syah,Muhibbin.2011.Psikologi Pendekatan Dengan Pendekatan Baru.Bandung:PT Remaja Rosda Karya Offset.

Uno,Hamzah B.2009.Model Pembelajaran Menciptakan Proses Belajar Mengajar yang Kreatif dan Efektif.Jakarta:Bumi Aksara.

Walgito,Bimo.2005.Bimbingan dan Konseling (Studi dan Karir).Yogyakarta: C.V. Andi Offset. 